\title{
Improving Sex Education Awareness of Students of Madrasah Ibtidaiyah Setia Budi Tamiajeng Trawas Mojokerto through Service-Learning Approach: A Community Service
}

\author{
Salis Khoiriyati, Eka Rizki Amalia, Widi Astuti \\ Institut Pesantren KH. Abdul Chalim Mojokerto \\ Email: salis85.sk@gmail.com; ekarizkiamalia2104@gmail.com; widi87849@gmail.com
}

\author{
Article History: \\ Received: Jan 11th 2021 \\ Revised: April 9th 2021 \\ Accepted: May 30 2021
}

Keywords: Sex Education,

Service-Learning Approach, students of Madrasah

Ibtidaiyah

\begin{abstract}
Abstract: Sex education should be given from an early age to prevent sexual harassment. Giving sex education to children is an effort to provide information about the function of the private parts. It makes them aware of sex and sexuality and the importance of taking them as privacy. It is also an opportunity to instill moral values and ethics. This community service employed a Service-Learning approach by utilizing adapted learning methods as well as adequate facilitators. In this program, sex education is given to grade 1 (as an early introduction) and grade 6 students (as they are approaching pre-puberty) at a primary school with material related to everyday life. This program ran for two weeks and received a satisfying response from the students and the school stakeholders. The result shows that the students understood the material very well. In addition, there is a reasonably positive behavior change in the students' awareness to take care of themselves in association with their classmates, especially those related to their private parts.
\end{abstract}

\section{Introduction}

Learning and education are the processes of transmitting knowledge from either the expert to the less capable one or even autonomous process by the self. Learning is considered more as an automatic process, but education refers to the more conservative one. Both learning and education are not simply transferring knowledge; instead, they facilitate the learners' reasoning through facts occurring in real-life contexts. 
Since the Covid-19 pandemic outbreak in 2020, students from all levels of education are forced to use digital technology such as computers and mobile phones to facilitate their learning. The education system changed drastically from the previous face-to-face and blended learning to complete online learning. This situation is unavoidable, and as a consequence, since the students have to use computers and mobile phones as communication devices almost every day, they are at risk of being exposed to the adult content of various kinds. It can be in the form of advertisements through social media and youtube channels. Even though the students are not searching by themselves, those dangerous contents might pop up unexpectedly. However, this undesirable situation is a challenge in this digital era. It should not cause excessive worries that lead to avoiding using those devices or careless attention that lead to ignorance of using the devices.

It is vital to equip children with appropriate information about sex and sexuality based on their age and stage of development to answer the challenges of the rapid growth of the digital era, especially related to precautions of the situation as mentioned earlier. It is not taboo to give sex education to children because it does not lead to promiscuity. Moreover, younger children are interested in pregnancy and babies rather than the mechanics of sex. Giving sex education also benefits open discussion and start communication with the children. They might have curiosity about parts of their body but feel uncomfortable talking about it. Beginning a small conversation about this early and continuing the talk as the child grows is the most suggested sex education strategy. It prevents the children from obtaining false information from irresponsible resources.

Sex education also benefits in helping the children understand about their body and helps them feel positive about their body. In this way, children will respect their body more as they understand that it is the private parts that must be protected. Unfortunately, there have been cases where underage children experience violence or sexual harassment. Some cases revealed that the victims were unaware that they were being abused. In 2021, the Integrated Service Center for Protection of Women and Children (Pusat Pelayanan Terpadu Perlindungan Perempuan dan Anak - PPTP2A) Mojokerto reported there were complaints about sexual harassments and abuses experienced by children. The cases informed that the children and the parents lack knowledge and information about sex education and how to protect themselves from sexual violence.

Based on the Department of Population Control data, Family Planning and Women's Empowerment (Dinas Pengendalian Penduduk, Keluarga Berencana dan Pemberdayaan Perempuan - DP2KBP2) Mojokerto Regency, in 2019, 19 children were victims of violence and perpetrators of violence. This number increased from 2018, only 17 cases, and some are sexual violence cases, with the Trawas district dominating the 
number. The subjects cover the average age range of about 13-17 years old. ${ }^{1}$

Two terms must be understood in the sex education context: education and sex. Education is the process of maturing humans through training and education. Another interpretation of education is transferring knowledge or developing the potentials of the subject being educated to achieve optimal development and civilizing humans through transforming central values. ${ }^{2}$

Law number 20 of 2003 concerning the national education system (Sistem Pendidikan Nasional - SISDIKNAS) also explains the meaning of education. In the article (1), it says that "education is a conscious and planned effort to create a learning atmosphere and learning process so that students are active in developing their abilities, to equip themselves with religious and spiritual strength, personality, selfcontrol, and noble character to be skilled and perform well for themselves, the society, the nation, and the country. ${ }^{3}$

The term 'sex' has two meanings, the first means gender, while the second means anything related to genitals, such as intercourse between men and women. ${ }^{4}$ According to the Department of National Population and Family Planning (Badan Kependudukan dan Keluarga Berencana Nasional - BKKBN), sex means gender. This characteristic distinguishes between male and female, while sexual means anything related to sex or what is triggered from it.

Sex education should be given from an early age to prevent sexual problems from developing. In Islamic teachings, sex education cannot be separated from religion, and even it entirely has to be built on a religious foundation in the hope to create a character of a responsible individual. Giving sex education to children is an effort to provide information about the function of the reproductive organs and at the same time instilling moral values and ethics.

Sex education is an effort to educate and direct sexual behavior correctly and adequately. Meaning, sexual behavior that emphasizes physical and psychological aspects will result in healthy sex both for the self and for the partner. ${ }^{5}$ In addition, sexual health problems often associated with various diseases caused by sexual intercourse or commonly known as sexually transmitted diseases (STD), are also explained. STDs such as gonorrhea, syphilis, chlamydia infections, chancroid, and genital herpes ${ }^{6}$ are also discussed. By knowing the examples and the risk of STDs, it is

\footnotetext{
${ }^{1}$ Sindonews.com. Accessed on June 3, 2021

${ }^{2}$ Chabib Thoha, Kapita Selakata Pendidikan Islam (Yogyakarta: Pustaka Belajar, 1996) pp. 99.

3 Undang-Undang Sistem Pendidikan Nasional (Jakarta: The Ministry of National Education of Republic Indonesia, 2003) pp. 6.

${ }^{4}$ Center for Language Development, Kamus Besar Bahasa Indonesia (Jakarta Balai Pustaka, 1992) pp. 93.

${ }^{5}$ A, Widjanarko., Sex Education dalam Pandangan Islam. Jakarta: Mostgam . 1995.

6 WH Maters , Johson \& Kolodny, Sex and Human Loving, New York: Little Brown and Company.
} 
hoped that individuals will be able to manage their sexual desire correctly and adequately according to the believed values and customs. One way to achieve this is by taking preventive measures, such as controlling sexual behavior, seeking information about STDs, knowing how to protect themselves from STDs, and sexual violence and harassment. How can the parents and children access any data of healthy sexual behavior and ways to protect the children? This community service program aimed to answer this problem by administering a 2-weeks program to educate children about sex education.

Information plays a significant role and impact in a person's life. Aristotle says a statement in Avin Fadilla can change a person's behavior based on what is desired by the information provider. In addition, the information can help a person overcome several problems encountered and makes a person better prepared to face unexpected situations. ${ }^{7}$ Concerning early sex education, there are several techniques for providing information on the development of the reproductive system and essential selfprotection. In this community service program, the team administered lectures and conducted discussions. The two techniques were expected to provide practical ways to inform the students and the parents.

What happens if an individual receives a persuasive message? According to persuasion theory from a cognitive perspective called The Elaboration Likelihood Model (ELM), namely two-way persuasion by Cacioppo, when someone receives a persuasive message, they will digest the information and make an argument. ${ }^{8}$ Then, how does persuasion happen? According to ELM, two possible routes relate to the amount of cognitive effort required. A central route will occur if the information message is considered essential and according to personal needs. The cognitive activity taking place is evaluating the strength and rationality of an argument. It then decides whether the content can be approved or not by the belief system. The central route will work only if the quality of the argument is compelling. When the message is unnecessary and irrelevant to personal needs, persuasion will occur in the peripheral route. In this case, the cognitive work is limited. If there is a change in attitude, it is more due to cuecue persuasion-information related to the source of prestige, credibility, or like and dislike factor, or to the form of the message presented and not on the quality of the argument. Lecturing is a technique that involves a more active role from the communicator. For the audience, the need for argumentation is relatively minor. Group discussion requires the ability to perform profound argumentation.

1986

7 Avin Fadilla \& Ira Paramasti, Efektifitas pendidikan seksual dini dalam meningkatkan pengetahuan perilaku seksual sehat, Gajah Mada University: Jurnal Psikologi. 1998. pp. 2534 \& Bacon. 1994

$8 \quad$ Byrne \& Baron, Social Psychology, Understanding human interaction. Singapore: Allyn 
As for the description above, Islamic Elementary School (Madrasah Ibtida'iyah MI) Setia Budi feels the need to provide physical and non-physical assistance to improve the quality of the school by administering the community service program on the topic of sex education. This school had never been conducted such socialization under that topic before thus it is significance to help this school providing and informing such essential topic for the students. In addition, the school is located in Trawas sub-district, where the dominant cases of sexual violence in Mojokerto district taking place.

\section{Method}

This community service was carried out with students of Institut Pesantren $\mathrm{KH}$ Abdul Chalim Mojokerto through Community Service Program (Kuliah Kerja Nyata KKN) and employing the Service Learning (SL) method. According to Sigmon (1996), Service Learning is an education-experience approach based on reciprocal learning. This learning is derived from service activities where the service provider (the college or university) serves and the community who receives the service learn together from shared experience. ${ }^{9}$

Sarena D. Seifer and Kara Cannors define Service-Learning as a learning strategy that integrates the service in the teaching and reflection activity to enrich learning experience, teach sole responsibility, and strengthen the community or society. 10 Service-learning is one of the learning methods administered by colleges or universities to connect education with the community and their needs. The basis of servicelearning is to carry out an educational process that provides services to the community, especially those economically disadvantaged.

Service-learning has the following definition:

- A method by which students learn and develop through active participation and experience in well-organized service activities that meet the community's needs. This method is integrated into the academic curriculum.

- Service-learning is a process that integrates a combination of volunteer community service with an active reflection into the curriculum to enrich and enhance student learning materials. ${ }^{11}$

Community involvement through service-learning is different from the standard community service in several ways:

- The balance between the service and search goals

- Reciprocal learning

${ }^{9}$ Writing Team Community Service (KKN) guide, Institut Pesantren KH Abdul Chalim.

10 Margareta WK, Nindya, Karin Oscarina, Kalonica Kay, Service Learning pada Mata Kuliah Desain Interior \& Styling 4 Program Study Desain Interior Petra Christian University Surabaya. Petra Christian University: 2017

11 Ibid 
- Emphasis on developing civic skills and achieving social change

- Focus on practice and reflective

- Emphasis on addressing the needs identified by the community and the integral involvement of community partners. ${ }^{12}$

This community service program aims to foster the students of MI Setia Budi Trawas to gain knowledge and collect information to enter the pre-puberty stage. Not many older people (parents, especially) are willing to discuss sex and sexuality. This topic is considered taboo to be addressed; thus, it rarely becomes a topic of discussion. Sex education is better taught earlier to avoid misunderstanding, misconception, and misinformation. Children need to obtain the correct information based on their age and stage of development from trusted resources. Otherwise, they might be exposed to harmful content from the internet and other unreliable resources. It is unavoidable that they might also experience sexual harassment due to the lack of understanding and information about the topic. Cultural approaches about sex education sometimes lead to conflict, but relatively depending on time, place, and circumstances. Moral values and beliefs might also differ significantly from one society to another. ${ }^{13}$

MI Setia Budi is an Islamic primary school located in Tamiajeng village Trawas district Mojokerto. The school applies a full-day system. The community service program was conducted after the researchers, and the team conducted observation and needs and situation analysis in the site. The program was arranged and organized based on the considerations: 1) The school's and the students' needs and benefits, and 2) the available infrastructure. The detail of the program is as follow.

13 Avin Fadilla Helmi \& Ira Parasmastri, Efektifitas pendidikan seksual dini dalam meningkatkan pengetahuan perilaku seksual sehat. Gajah Mada University. Journal of Psychology. No. 2. 1998. pp. 25-34 


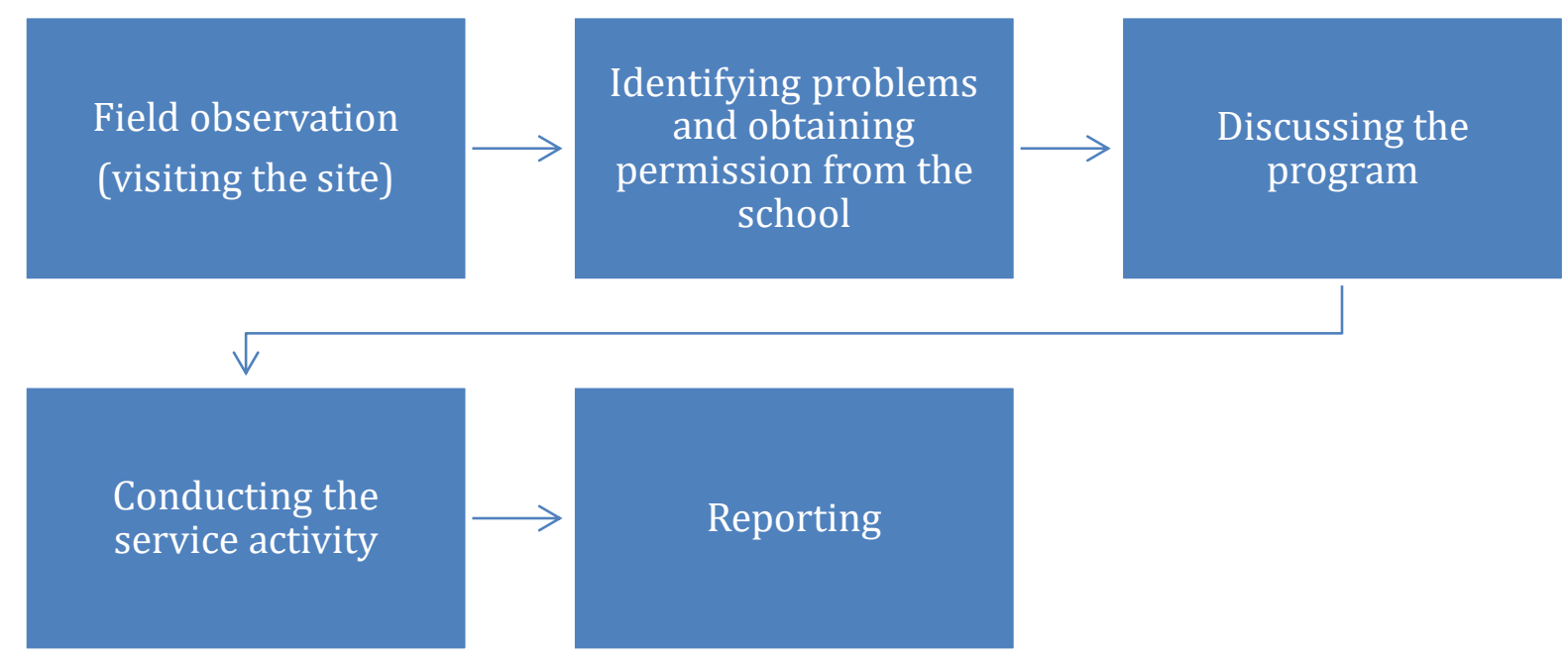

Figure 1. The service community program

\section{Results}

The community service program was carried out through the socialization of sex education material. According to Andika, sex education is learning about reproductive health, which is essential to the family and the school. Sex education aims to provide insight by introducing children to gender and how to take care of themselves, both in terms of their health and everything related to the reproductive system. ${ }^{14}$ Sex education is also an attempt to raise awareness and delivering information about issues of sexuality in the form of knowledge about the functions of reproductive organs and at the same time instilling moral values, ethics, commitment, and religious principles. It aims to prevent any form of abuse and harassment and irresponsible practice of sexual perversion. ${ }^{15}$

The material on sex education delivered to children should be appropriate with their ages and level of development. In this community service program, the materials cover the names of body parts, understanding how to care for and taking care of the body parts, especially the personal aspects and knowing the 'underwear rules'. Parents are also suggested to participate in giving sex education to children. They can start by asking about their desire, providing guidance on the importance of protecting and

14 Elegant Permatasari, Ginan Sasmito Adi, Gambaran pemahaman anak usia sekolah dasar tentang Pendidikan seksual dalam upaya pencegahan kekerasan seksual pada anak, Jurnal Vol. 9 No. 1 (December 1, 2017).

15 Justicia R., program underwear rules untuk mencegah kekerasan seksual pada anak usia dini. Jurnal Pendidikan anak usia dini, Vol. 9 No. 2. 2017. Pp. 217-229 
keeping their sex organs healthy, and providing insight into the behavior of healthy relationships and the risks that can occur about sexual problems. ${ }^{16}$ Sex education can also discuss the development of sexuality, reproductive health, and gender roles. Sex education includes aspects of biology, socio-culture, psychology, and spirituality from the perspective of cognitive, attitude, and behavioral aspects, including the ability to communicate and make decisions. ${ }^{17}$

Solihin asserts that sex education has several objectives, the children: (1) will experience changes either biological, psychological and psychosexual change as a result of human growth and development, (2) obtain information about the function of the human reproductive organs so they will take good care of their private parts, (3) obtain information and understanding about ethics, and various sexual misconducts that should be avoided, (4) understand the consequence of sexual abuse that can endanger their physical and psychological health. In addition, the objectives of sex education include: (1) providing lessons on the role of sex, especially on biological topics such as pregnancy, menstruation, puberty, and so on, (2) providing an understanding of the proper attitudes and behavior in building a relationship with the opposite sex, (3) prevent unwanted sexual abuse, (4) distinguishing which actions belong to sexual harassment and violence and which are not, (5) preventing children from becoming victims or even perpetrators of sexual harassment, and (6) fostering a courageous attitude to report any sexual harassment. It can be concluded that sex education is an essential thing that must be given to children as early as possible to inform them to understand their bodies and provide them with information on how to protect themselves from sexual crimes. ${ }^{18}$

The implementation of this community service program is through the delivering materials about the importance of sex education, how to keep the reproductive organs, how to take care of self from sexual violence, socialization on how to keep the sexual organs clean and healthy, and the preparation to enter the puberty stage. The implementation of this program aimed to equip children with any necessary information to avoid sexual violence, introduce children to gender, and take care of them both in terms of health, hygiene, security, and safety.

The program was conducted for two weeks, with six meetings during school hours. At the beginning of the learning class, the teacher first delivered an introduction material, then continued explaining the material from 08:30 a.m. to 11 a.m. The program received attentive responses from the principal and the teachers because the topic and the materials delivered were vital for the students to master.

16 Ibid

17 Solihin, Pendidikan seks untuk anak usia dini. Jurnal Pendidikan sekolah dasar. Vol . 1 No. 2. 2015. Pp. 58-63

18 Ibid 
Several factors support increasing the ability of children's self-protection and knowledge related to sex education, i.e., the learning method used, the material provided, and the quality of the facilitator. A simulation method with visual aids and role-playing were used as the method to deliver the material. Maurer emphasized the need for visual aids, repetition of keywords, simple delivery of material, humor, lots of games, and the involvement of all cognitive, affective, and psychomotor elements to try to train certain attitudes and actions to avoid exploitative sexual behavior on children. ${ }^{19}$

After the program was completed, there was a positive change in students' behavior. Prior to this activity, many students often joked by holding each other's body parts which are sensitive areas. To prevent violence and sexual harassment issues, an introduction to the material "My body is mine" was given. The material consisted of underwear rules, private areas such as the chest, underwear, and buttocks that only certain people can touch, such as themselves and their mothers. Justicia suggests that this can help children to understand many things, namely: (1) her body is hers, the underwear and chest area are private parts, (2) there are accepted and unaccepted touch that makes uncomfortable, (3) good and bad secrets, (4) methods of prevention and protection. After the sessions, the students understood that joking by touching other people's sensitive areas should be avoided.

\section{Discussion}

One of the efforts to raise and increase awareness about self-protection from the sexual exploitation of children is by administering sex education programs. This community service program shows that effectiveness of sex education to improve the children's ability to self-protect from sexual exploitation. The sex education program can be implemented and become part of the school agendas and routine activities.

This community service program contributed to positive changes in behavior and additional knowledge related to sex and sexuality. For example, children casually joked around their private parts and touched them without feeling uncomfortable. However, after the program was carried out, they understood that the action was inappropriate and it can lead to sexual harassment. The children were also aware of the importance of self-protection, especially in a situation that is deemed dangerous and can lead to sexual violence. Before, some children did not even realize that certain actions could be considered sexual harassment or sexual violence. This proves that this community service program was successful and contribute a lot to children's understanding of the topic.

${ }^{19}$ DW. Haffner, Sex education: A call to Action. New York: Sex Information and education of US. 1995. 
The sex education program consists of a wide range of knowledge and skills given as part of efforts to protect children from sexual exploitation. This program can be integrated into the school curriculum. The material provided can be synergized with other materials for children depending on the children's age. This must be introduced to children early to be a preventive effort in overcoming the tendency of sexual exploitation behavior in children.

\section{Conclusion}

Sex education is vital to be given since children are at an early age. This is a prevention method to occupy children with necessary information about their sex and sexuality. The children might learn incomplete and incorrect information from their friends and social media, which can be demeaning or even dangerous. Children can be exposed to inappropriate content from social media, depicting the most sensational and superficial sense. The portrayal is often unrealistic and appears without context or relationship components. Therefore, children might get a false interpretation of the most crucial topic about this topic according to their age. This can lead to improper behavior and sexual harassment into and from peers. 
In this community service program, sex education was given to grade 1 and grade 6 students at the primary school level. The following program can be given to students at the junior high school level experiencing puberty and emotional ups and downs. They are also in their critical age to experiencing their sexuality. If it is not directed and appropriately managed, it might cause unwanted occurrences such as sexual abuse and harassment. Thus, the material about sex education is vital. This can become a suggestion for the school to consider administering sessions on sex education and incorporate it into the school curriculum.

\section{Acknowledgments}

The community service (KKN) team would like to acknowledge the Institut Pesantren KH Abdul Chalim Mojokerto for the support in this program. We also want to send our gratitude to the stakeholders, especially the students of MI Setia Budi Trawas Mojokerto, for this program's impressive participation and cooperation.

\section{References}

Baron, Byrne, Social Psychology Understanding Human Interaction, Singapore: Allyn \& Bacon. 1994

Fadilla, Avin \& Ira Paramasti, Efektifitas Pendidikan seksual Dini dalam meningkatkan pengetahuan perilaku seksual sehat, Universitas Gajah Mada : Jurnal Psikologi. ISSN : 0215-8884. 1998. pp 25-34

Sindonews.com. Accessed on June 3, 2021.

Haffner, D.W., Sex education: A call to Action. New York: Sex Information and Education of US. 1995.

Margareta, Nindya, Karin Oscarina, Kalonica Kay, Service Learning Pada Masa Kuliah Desain Interior \& Styling 4 Program Study Desain Interior Universitas Kristen Petra Surabaya. Petra Christian University: 2017

Maters, W. H., Johson \& Kolodny, Sex and Human Loving, New York: Little Brown and Company. 1986.

Permatasari, Elok, Ginan Sasmito Adi, Gamabaran pemahaman Anak Usia Sekolah Dasar Tentang Pendidikan Seksual DAlam Upaya Pencegahan Kekerasan Seksual Pada Anka, Jurnal Vol. 9 No. 1 (1 Desember 2017).

Pusat pembinaan dan Pengembangan Bahasa, Kamus Besar Bahasa Indonesia (Jakarta: Balai Pustaka, 1992) pp. 93.

R., Justicia, program underwear rules untuk mencegah kekerasan seksual pada anak 
usia dini. Jurnal pendidikan anak usia dini, Vol. 9 No. 2. 2017. Hal. 217-229

Solihin, Pendiidkan seks untuk anak usia dini. Junal pendidian sekolah dasar, Vo. 1 No. 2 . 2015. Hal 58-63

Thoha, Chabib, Kapita Selakata Pendidikan Isam (Yogyakarta: Pustaka Pelajar, 1996) pp. 99.

Tim Penulis panduan KKN ikhac

Undang-undang. Sisitem Pendidikan Nasional, (Jakarta : Dapertemen Pendidikan Nasional RI, 2003) pp. 6.

Widjanarko, A., Sex Education dalam Pandangan Islam. Jakarta: Palinggam. 1995. 